\title{
Parametric Study of Behaviour of Box Girder Bridges Under Different Radius of Curvature
}

\author{
Jefeena Sali ${ }^{1}$, Kashif Quamar Inqualabi ${ }^{2}$, Reji P Mohan ${ }^{3}$ \\ ${ }^{1}$ PG Scholar, Structural Engineering, SBCE,Pattoor,Kerala \\ ${ }^{2}$ Research Scholar, CRRI, Delhi \\ ${ }^{3}$ Assistant Professor, Department of Civil Engineering, SBCE,Pattoor,Kerala
}

\begin{abstract}
Box girders are now prominently used in freeway and bridge systems due to their structural efficiency, better stability, serviceability, economy of construction and pleasing aesthetics They are most suited for bridges curved in plan because of its high torsional rigidity. A study of box girder curved in plan with trapezoidal cross section has been carried out in the present investigation. The analysis is carried under the dead load, super imposed dead load, live load of IRC Class A tracked vehicle and prestressed load .This paper focus on the parametric study of box girders with different radius of curvature by keeping the span, cross sectional shape and material properties constant. The parametric investigations performed on curved box girders helps to evaluate the effects of change in radius of curvature on the behaviour of the box girders. This study would enable bridge engineers to better understand the behaviour of curved box girders and the results presented will be a valuable guidance to them.
\end{abstract}

Keywords: Box Girder,Stability,Torsional Rigidity,Radius of curvature

\section{Introduction}

The spanning of the bridge started with simple slabs. When the width of the bridge deck is increased the number of longitudinal beams to be used has also increased which leads to reduction of stiffness in the transverse direction and relatively high transverse bending. Under high transverse bending the webs could no longer be in their original position and to keep then in their original position the bottom bulb of the webs are to be tied together. This leads to the evolution of box girder. The box girders can be of different forms and geometry. A box girder is particularly well suited for use in curved bridge systems due to its high torsional rigidity resulting in better transverse load distribution. High torsional rigidity enables box girders to effectively resist the torsional deformations encountered in curved thin-walled beams The increase in flange width of box girder makes it possible to use large span/depth ratios. This is an advantage if construction depth is limited. Also it can lead to more slender structures which are aesthetically pleasant.

Analysis and design of box-girder bridges are very complex due to its three dimensional behaviours consisting of torsion, and bending in longitudinal and transverse directions. Analysis and design of the box girder can be divided into two parts i.e. longitudinal analysis (i.e.analysis along traffic direction) and transverse analysis (i.e. across traffic direction). In Longitudinal direction the bending moment, shear and torsion of the curved box girders varies with the different spans lengths and radius. In each analysis method, the three-dimensional bridge structure is usually simplified by means of assumptions in the geometry, materials and the relationship between its components. The accuracy of the structural analysis is dependent upon the choice of a particular method and its assumptions.In each analysis method, the three-dimensional bridge structure is usually simplified by means of assumptions in the geometry, materials and the relationship between its components. Available research works on some methods are grillage analogy method, orthotropic plate theory method, folded plate method, finite strip method, finite element method, computer programming and experimental studies.

\section{Literature Review}

There are several literatures on straight and curved box girder bridges dealing with analytical formulations to understand the behaviour of these complex structural systems. Some experimental studies are undertaken to investigate the accuracy of existing elastic analysis methods like finite element method, finite strip method and so on. There are also research works on single cell and multicell box girders and the investigations on them are classified into investigations using folded plate elements and investigations using box beam elements. W.Y.Li et al.[1]Employed three examples of box-girder bridges of different geometrical shapes to demonstrate the accuracy and versatility of the finite strip method. Kaoru et al.[2]Provided the information required to formulate an effective width rule for design of curved girder bridges and the theory used in this analysis is the refined beam theory. Yasunori et al.[3]Investigated on response and slip behaviour of curved composite box girders with end diaphragms and also conducted a parametric study to evaluate the effect of cross sectional deformation on the stresses of the girders. Nabeel and Conrad [4] conducted a study of seismic response of curved steel box girder bridges under seismic loading. Khaled and John [5] Conducted a parametric study on multi cell box girderbridges using finite element method and these bridges are subjected to AASHTO truck loading as well as dead load. Khaled and John [6] Used an experimentally calibrated finite-element model to conduct a parametric study of multiple steel box girder bridge and determined the shear distribution characteristics under dead load and AASHTO live loadings. Ayman et al [7] Conducted a detailed investigation of warping related

Volume 5 Issue 6, June 2016 


\section{International Journal of Science and Research (IJSR) \\ ISSN (Online): 2319-7064 \\ Index Copernicus Value (2013): 6.14 | Impact Factor (2015): 6.391}

stress of composite steel concrete box girder bridges of different radius of curvature and span length. Byung and Chai [8] Examined the prebuckling stress distribution and elastic and inelastic buckling stresses of horizontally curved stiffened flanges and investigated on the effect of important design parameters on the minimum required stiffener rigidity. Gupta et al. [9] Conducted a parametric study on behaviour of box girder bridges under different shape and depth of the cross section.

\section{Problem Definition}

A flyover in Trivandrum, Kerala which is a prestressed trapezoidal box girder bridge is adopted as a design example for the study. It is a $400 \mathrm{~m}$ long and $11 \mathrm{~m}$ wide flyover with three lanes for traffic. Only a particular span of $32 \mathrm{~m}$ between two piers is chosen for the study.The span is considered as simply supported and the restraining effect of slab is not considered.

In this study 5 models (among which one is straight and the other four are curved in plan) are analysed using finite element software CSI Bridge. These box girders are analysed to study the comparison of straight and curved box girder bridges in terms of deflection, bending moment, torsion, and longitudinal stress under different loading conditions along the length of the span. The main objectives of this study are

- To Study the behaviour of curved box girder bridge compared to a straight bridge.

- To study the impact of radius of curvature on the behaviour of box girder bridges.

The plan of the entire flyover and the cross sectional view of the box girder bridge is shown in Fig. 1 and Fig. 2 respectively.

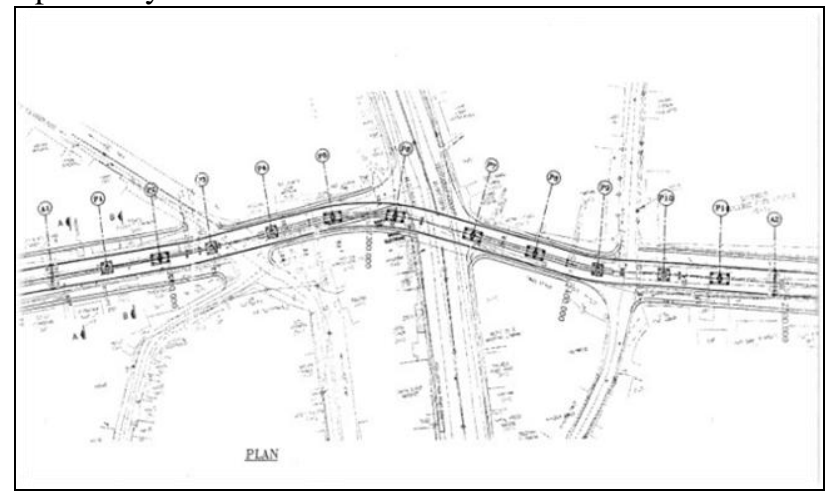

Figure 1: Plan of the flyover in Trivandrum city

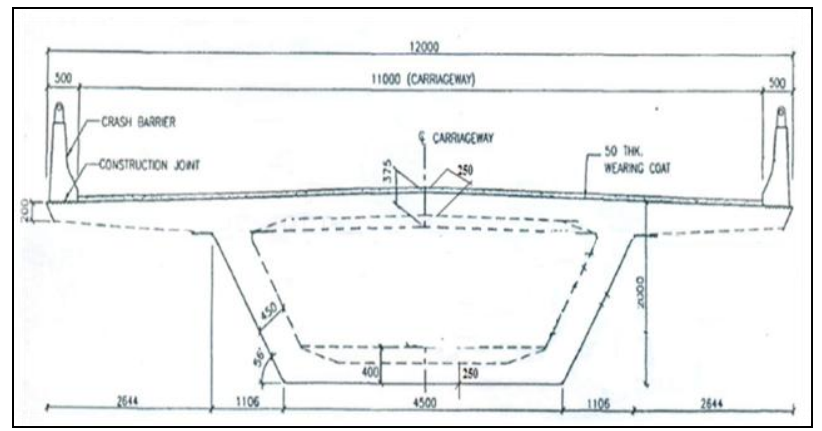

Figure 2: Cross-sectional dimensions of Trapezoidal Box Girder
The finite element modelling of one straight and four curved bridges are conducted in CSI Bridge. The curved box girder model is made using Bridge module with shell elements of CSI Bridge. Four curved bridges are modelled having radius of curvatures $75 \mathrm{~m}, 100 \mathrm{~m}, 150 \mathrm{~m}$ and $200 \mathrm{~m}$. A straight and curved single cell trapezoidal prestressed box girder bridge modelled CSI Bridge is shown in Fig. 3

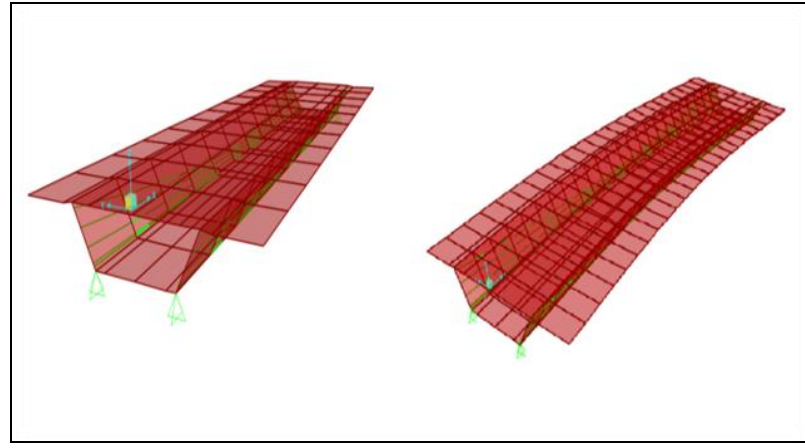

Figure 3: Straight and curved trapezoidal box girders modelled in CSI Bridge software

\subsection{Material Properties}

The box girder considered for the analysis is prestressed concrete box girder. The material properties are given in Table 1.

Table 1: Material properties

\begin{tabular}{|c|c|}
\hline Material Properties & Values \\
\hline Weight /unit volume & $25000 \mathrm{~N} / \mathrm{m}^{2}$ \\
\hline Young's modulus (E) & $32500 \mathrm{e}^{6} \mathrm{~N} / \mathrm{m}^{2}$ \\
\hline Poisson's ratio (v) & 0.15 \\
\hline Shear Modulus (G) & $1.413 \mathrm{e}^{10} \mathrm{~N} / \mathrm{m}^{2}$ \\
\hline Coefficient of thermal expansion (A) & $1.17 \mathrm{e}^{-5} /{ }^{0} \mathrm{C}$ \\
\hline Specific compressive strength of concrete (fc') & $45 \mathrm{e}^{6} \mathrm{~N} / \mathrm{m}^{2}$ \\
\hline
\end{tabular}

\subsection{Design Loads}

The loads that are considered on the superstructure of the box girder bridge are listed below.

- Dead load and superimposed dead load (DL+SIDL). The self-weight of the structure is the dead load and superimposed dead load is that load from wearing coat and crash barriers.

- Moving load: The live load is considered as per IRC: 62010. I.R.C ClassA. Tracked Vehicle loading are applied on the box girder as lane loads.

- Prestressed load. The prestressing tendons provide clamping load which produces compressive stress to balance the tensile stressexperienced by the concrete due to bending load.

\section{Methodology}

- A flyover in Kerala which is a prestressed trapezoidal box girder bridge is chosen for the study. The cross sectional details are collected and a $32 \mathrm{~m}$ span of flyover has been modelled and analysed.

- Four other models with same cross sectional details and different radii are also modelled in CSI Bridge software. Thus one straight and four curved box girders (with 


\section{International Journal of Science and Research (IJSR) \\ ISSN (Online): 2319-7064}

Index Copernicus Value (2013): 6.14 | Impact Factor (2015): 6.391

constant span length, cross section and material properties but different radii) in total are considered in the present investigation.

- All the five models are subjected to dead load superimposed dead load, moving load (3 lanes of IRC Class A tracked vehicle) and prestressed load.

- A static analysis for dead load moving load and prestressed load are performed. The longitudinal stress at top and bottom of cross sections, bending moment, torsion, and deflection under all loading conditions, are recorded.

- The responses of a box girder straight and curved in plan and are compared.

\section{Results and Discussions}

A straight trapezoidal box girder and horizontally curved trapezoidal box girders of radius $75 \mathrm{~m}, 100 \mathrm{~m}, 150 \mathrm{~m}$ and $200 \mathrm{~m}$ are analysed and the graphs of deflection, bending moment torsion and longitudinal stress of straight and curved box girders under different load combinations are presented.

\subsection{Variation of bending moment with change in radius of curvature}

It is observed that the bending moment is least for the straight box girder and the bending moment increases with decrease in radius of curvature under all loading conditions. The bending moment increases by around $5 \%$ from infinity to radius $100 \mathrm{~m}$ and increases by around $6 \%$ from radius $100 \mathrm{~m}$ to $75 \mathrm{~m}$ under DL and SIDL. The bending moment increases by around $7 \%$ from infinity to radius $100 \mathrm{~m}$ and increases by around $9 \%$ from radius $100 \mathrm{~m}$ to $75 \mathrm{~m}$ under prestressed load. The variation of bending moment with change in radius under DL+SIDL and prestressed load are shown in fig. 4 and fig. 5 and percentage increase in bending moment under moving load is given in Table 2.

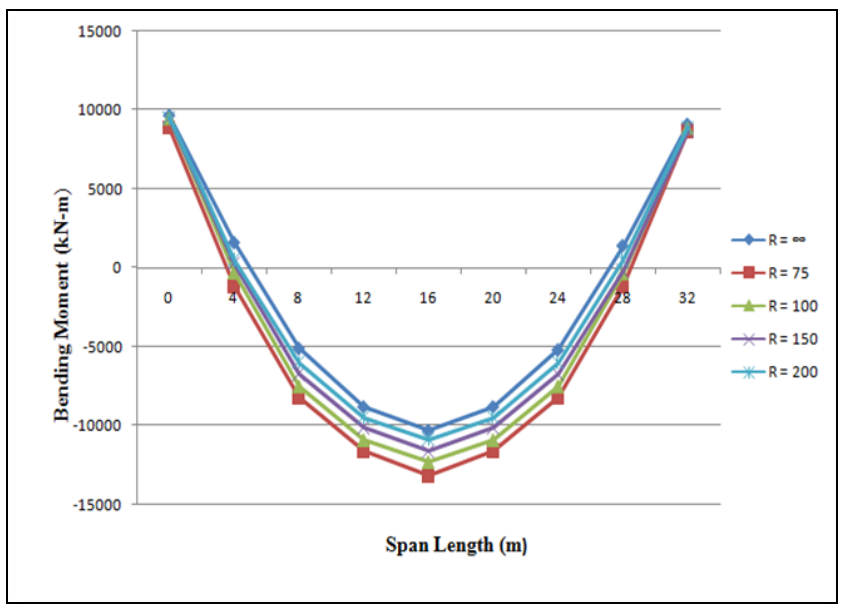

Figure 4: Variation of bending moment along span under $\mathrm{DL}+\mathrm{SIDL}$

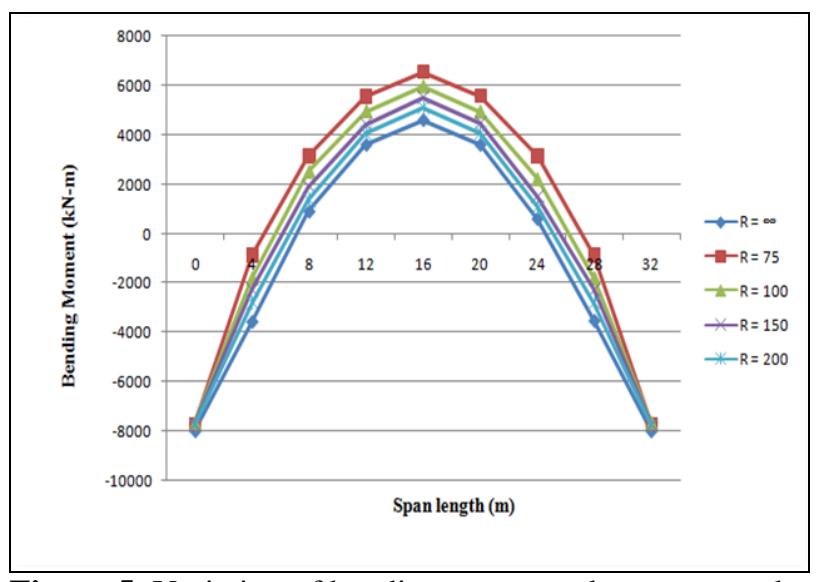

Figure 5: Variation of bending moment along span under prestressed load

Table 2: Percentage increase of maximum bending moment along span under moving load

\begin{tabular}{|c|c|c|}
\hline Radius $(m)$ & $\begin{array}{c}\text { Maximum bending } \\
\text { moment } \\
(k N-m)\end{array}$ & $\begin{array}{c}\text { Percentage } \\
\text { Increase }\end{array}$ \\
\hline $\mathrm{R}=\infty$ & 3696 & $3.4 \%$ \\
\hline $\mathrm{R}=200$ & 3823 & $4.5 \%$ \\
\hline $\mathrm{R}=150$ & 3995 & $7 \%$ \\
\hline $\mathrm{R}=100$ & 4202 & $7 \%$ \\
\hline $\mathrm{R}=75$ & 4496 & \\
\hline
\end{tabular}

\subsection{Variation of deflection with change in radius of curvature}

The deflection along the span for the box girders increases with decrease in radius of curvature and the deflection is least for straight box girder under all loading conditions. The deflection increases by around $2 \%$ from infinity to radius $100 \mathrm{~m}$ and increases by around $6 \%$ from radius $100 \mathrm{~m}$ to $75 \mathrm{~m}$ under DL and SIDL. The deflection increases by around 5\% from infinity to radius $100 \mathrm{~m}$ and increases by around $9 \%$ from radius $100 \mathrm{~m}$ to $75 \mathrm{~m}$ under prestressed load. The percentage increase in deflection under moving load is given in Table 3. The variation in deflection under DL+SIDL and prestressed load is shown in Fig.6 and Fig. 7

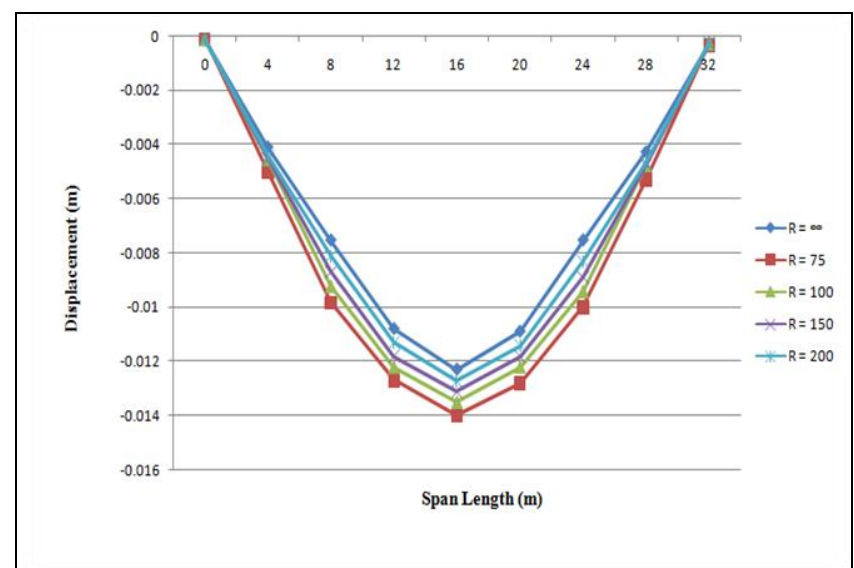

Figure 6: Variation of deflection along the span under DL+SIDL 
International Journal of Science and Research (IJSR)

ISSN (Online): 2319-7064

Index Copernicus Value (2013): 6.14 | Impact Factor (2015): 6.391

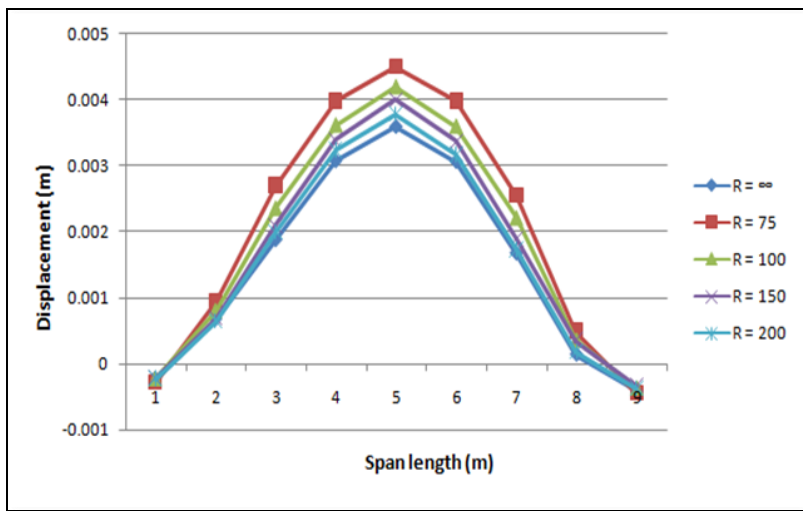

Figure 7: Variation of deflection along the span under prestressed load

Table 3: Percentage increase of maximum deflection along span under moving load

\begin{tabular}{|c|c|c|}
\hline Radius $(m)$ & Maximum displacement $(\mathrm{m})$ & $\begin{array}{c}\text { Percentage } \\
\text { Increase }\end{array}$ \\
\hline $\mathrm{R}=\infty$ & 4.35 & \multirow{5}{*}{$\begin{array}{l}3.4 \% \\
3.6 \% \\
4.8 \% \\
7.1 \%\end{array}$} \\
\hline $\mathrm{R}=200$ & 4.51 & \\
\hline $\mathrm{R}=150$ & 4.72 & \\
\hline $\mathrm{R}=100$ & 4.95 & \\
\hline $\mathrm{R}=75$ & 5.30 & \\
\hline
\end{tabular}

\subsection{Variation of torsion with change in radius of curvature}

The torsion along the span for the box girders increases with decrease in radius of curvature and the torsion is negligible for straight box girder under all loading conditions. The torsion increases by around $27 \%$ from radius $200 \mathrm{~m}$ to $150 \mathrm{~m}$ and from radius $150 \mathrm{~m}$ to $100 \mathrm{~m}$ and increases by around 42 $\%$ from radius $100 \mathrm{~m}$ to $75 \mathrm{~m}$ underDL and SIDL. The torsion increases by around $38 \%$ from radius $200 \mathrm{~m}$ to $150 \mathrm{~m}$ and from $150 \mathrm{~m}$ to $100 \mathrm{~m}$ and increases by around $50 \%$ from radius $100 \mathrm{~m}$ to $75 \mathrm{~m}$ under prestressed load. The percentage increase in torsion under moving load is given in Table 4. The variation in torsion under DL+SIDL and prestressed load is shown in Fig. 8 and Fig.9

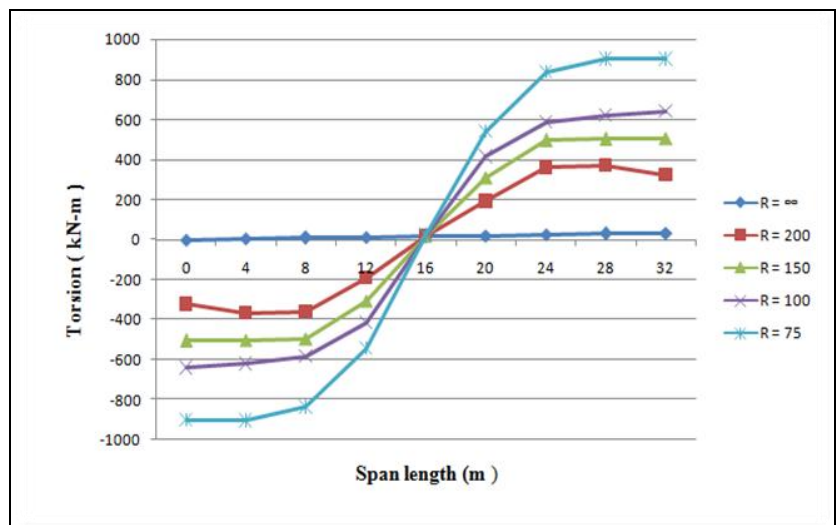

Figure 8: Variation of torsion along the span under DL+SIDL

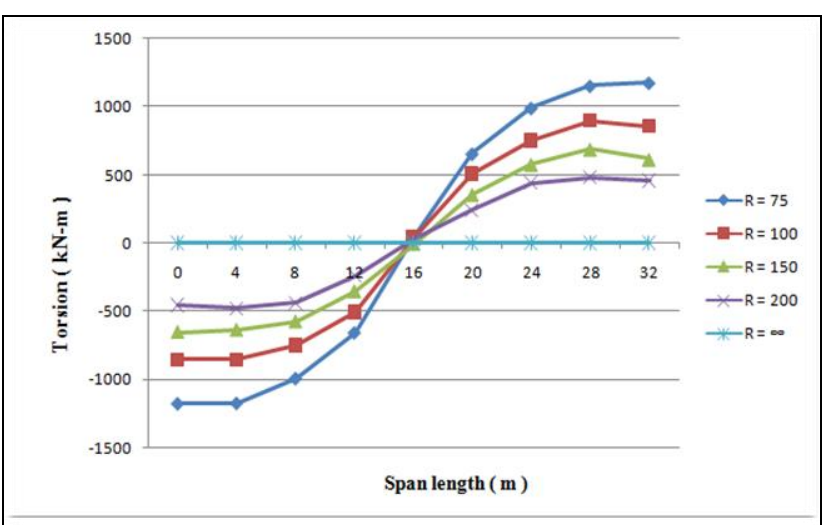

Figure 9: Variation of torsion along the span under prestressed load

Table 4: Percentage increase of maximum torsion along the span under moving load

\begin{tabular}{|c|c|c|}
\hline Radius $(m)$ & $\begin{array}{c}\text { Maximum Torsion } \\
(k N-m)\end{array}$ & $\begin{array}{c}\text { Percentage } \\
\text { Increase }\end{array}$ \\
\hline $\mathrm{R}=\infty$ & 1.03 & \\
\hline $\mathrm{R}=200$ & 1855 & --- \\
$=150$ & 2150 & $15 \%$ \\
$=100$ & 2499 & $31 \%$ \\
\hline $\mathrm{R}=75$ & 3200 & \\
\hline
\end{tabular}

\subsection{Variation of Longitudinal Stress (top and bottom of central part of cross section) with change in radius of curvature}

The longitudinal stress at top and bottom of the centre part of the cross section increases with decrease in radius of curvature of the box girder.The longitudinal stress is least for the straight box girder both at the top and bottom of the central part of the cross section. The longitudinal stress at top increases by around $4.5 \%$ from radius infinity to radius $100 \mathrm{~m}$ and increases by around $5.5 \%$ from radius $100 \mathrm{~m}$ to 75 $\mathrm{m}$ while longitudinal stress at bottom increases by around $4.2 \%$ from radius infinity to radius $100 \mathrm{~m}$ and increases by around $6.2 \%$ fromradius $100 \mathrm{~m}$ to $75 \mathrm{~m}$ under DL+SIDL. The longitudinal stress at top increases by around $5.7 \%$ from radius infinity toradius $100 \mathrm{~m}$ andincreases by around $6.5 \%$ from radius $100 \mathrm{~m}$ to $75 \mathrm{~m}$ while longitudinal stress at bottom increases by around $5.2 \%$ from radius infinity to radius $100 \mathrm{~m}$ and increases by around $6 \%$ from radius $100 \mathrm{~m}$ to $75 \mathrm{~m}$ under DL+SIDL. The percentage increase in longitudinal stress at top and bottom of the centre part of the cross section is given in Table 5. The variation of longitudinal stress at top and bottom of the centre part of the cross section under DL+SIDL and prestressed load are shown in Fig. 10 and Fig 11. 


\section{International Journal of Science and Research (IJSR) \\ ISSN (Online): 2319-7064}

Index Copernicus Value (2013): 6.14 | Impact Factor (2015): 6.391

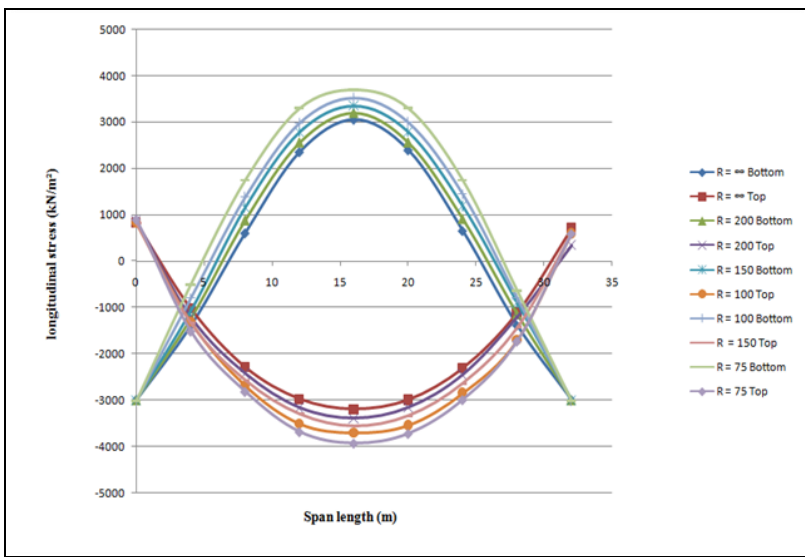

Figure 10: Variation of longitudinal bending stress along the span under DL+SIDL

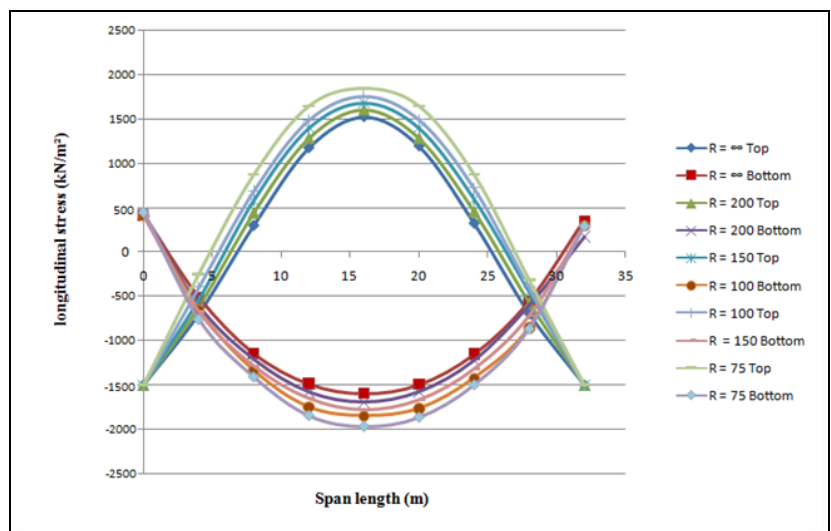

Figure 11: Variation of longitudinal bending stress along the span under prestressed load

Table 5: Percentage increase of maximum longitudinal stress along the span under moving load

\begin{tabular}{|c|c|c|c|c|}
\hline $\begin{array}{l}\text { Radius } \\
\text { (m) }\end{array}$ & $\begin{array}{l}\text { Longitudinal } \\
\text { stress (Top) } \\
\left(\mathrm{kN} / \mathrm{m}^{2}\right)\end{array}$ & $\begin{array}{c}\text { Percentage } \\
\text { Increase }\end{array}$ & $\begin{array}{l}\text { Longitudinal } \\
\text { stress(Bottom) } \\
\qquad\left(\mathrm{kN} / \mathrm{m}^{2}\right)\end{array}$ & $\begin{array}{r}\text { Percentag } \\
\text { Increase }\end{array}$ \\
\hline $\mathrm{R}=\infty$ & 1352 & \multirow{5}{*}{$\begin{array}{c}3 \% \\
3.2 \% \\
3.5 \%\end{array}$} & 1399 & \multirow{5}{*}{$\begin{array}{c}3 \% \\
3.4 \% \\
3.5 \%\end{array}$} \\
\hline $\mathrm{R}=200$ & 1392 & & 1442 & \\
\hline $\mathrm{R}=150$ & 1436 & & 1491 & \\
\hline $\mathrm{R}=100$ & 1486 & & 1553 & \\
\hline $\mathrm{R}=75$ & 1548 & & 1602 & \\
\hline
\end{tabular}

\section{Conclusions}

The analysis of one straight box girder and four curved box girders of different radius of curvature are carried out in CSI Bridge software.The results presented in this paper highlight the effects of radius of curvature of the box girder on the behaviour in terms of development of deflection longitudinal bending stresses and torsion. The conclusions that are drawn from the analysis of box girders of different radius of curvature are as follows

- As radius of curvature of box girder increases the deflection, bending moment, torsion and longitudinal bending stress along the span decreases.

- There is no significant variation in bending moment, deflection longitudinal bending stresses under DL+SIDL, moving load and prestressed load for specific span length with different radii.

- The torsional moment increases greatly with decrease in radius of curvature under all loading conditions.
- There is more variation in torsion with span radius below $100 \mathrm{~m}$ therefore its better to avoid such sharp curves and if they are unavoidable then structural changes to cross sectional dimension,must be made to stabilise the box girders.

\section{References}

[1] W. Y. Li ,L. G. Tham and Y. K. Cheung "Curved Box Girder Bridges" Journal of Structural Engineering, ASCE, Vol. 114, No.6, June, 1988. ()

[2] Kaoru Hasebe, Seizo Usuki, and Yasushi Horie "Shear Lag Analysis And Effective Width Of Curved Girder Bridges" Journal of Engineering Mechanics, ASCE ,Vol.111, January, 1985.

[3] Yasunori Arizumi, Sumio Hamada and Takeshi Oshiro"Behaviour Study Of Curved Composite Box Girders" Journal of Engineering Mechanics, ASCE Vol. 114, No. 11,November, 1988

[4] M. Nabeel Abdel-Salam and Conrad P. Heins "Seismic Response Of Curved Steel Box Girder Bridges" Journal of Structural Engineering, ASCEVol. 114, No. 12, December, 1988.

[5] Khaled M. Sennah and John B. Kennedy "Load Distribution Factors For Composite Multicell Box Girder Bridges "Journal Of Bridge Engineering , Vol 1, pp.71-78,February, 1999

[6] Khaled M. Sennah and John B. Kennedy "Design for Shear in Curved Composite Multiple Steel box Girder Bridges"Journal Of Bridge Engineering, ASCE Vol. 8, May 1, 2003.

[7] Ayman M. Okeil,and Sherif El-Tawil, "Warping Stresses in Curved Box Girder Bridges: Case Study" Journal of Bridge Engineering, Vol. 9,pp.487-496, September1,2004

[8] Byung H. Choi and Chai H. Yoo "Strength of Stiffened Flanges in Horizontally Curved Box Girders"Journal of Engineering Mechanics, ASCE ,Vol.131,pp.167176,February1,2005.

[9] P.K. Gupta, K K Singh and A. Mishra "Parametric Study On Behaviour Of Box-Girder Bridges Using Finite Element Method"Asian Journal of Civil Engineering (Building And Housing) Vol. 11, pp.135148 (2010)

[10]IRC: 6- 2010, Standard specifications and code of practice for road bridges, Section- II: Loads and stresses.

[11]IRC: 21- 2000, Standard specifications and code of practice for road bridges.

[12]IRC : 18-2000. Design Criteria. For. Prestressed Concrete Road. Bridges. (Post-Tensioned Concrete).

[13] IS 1343 : Code Of Practice For Prestressed Concrete

\section{Author Profile}

Jefeena Sali is PG Scholar, Structural Engineering, Sree Buddha College of Engineering,Pattoor, Kerala. She is pursuing Master of Technology in Structural Engineering from University of Kerala. Did Bachelor of Technology in Civil Engineering from University of Kerala

Kashif Quamar Inqualabi is Research Scholar, CSIR-Central Road Research Institute, New Delhi. In 2014 did Master of Technology in Structural Engineering from Academy of Scientific

\section{Volume 5 Issue 6, June 2016 www.ijsr.net}




\section{International Journal of Science and Research (IJSR) \\ ISSN (Online): 2319-7064}

Index Copernicus Value (2013): 6.14 | Impact Factor (2015): 6.391

and Innovative Research, CRRI, New Delhi. Bachelor of

Technology in civil engineering in 2011 from Aligarh Muslim

University

Reji P Mohan is Asst. Professor , Department of Civil Engineering, Sree Buddha College of Engineering,Pattoor, Kerala. In 2009 did Master of Technology in Structural Engineering from NIT,Calicut and Bachelor of Technology in civil engineering in 2007 from TKM College of Engineering, Kollam

Volume 5 Issue 6, June 2016 www.ijsr.net 